Revision \#1

27 May 2016

\title{
Transition of Vegetation States Positively Affects Harvester Ants in the Great Basin, USA
}

Joseph D. Holbrook ${ }^{\mathrm{a} *}$, David S. Pilliod ${ }^{\mathrm{b}}$, Robert S. Arkle ${ }^{\mathrm{c}}$, Janet L. Rachlow ${ }^{\mathrm{d}}$, Kerri T. Vierling ${ }^{\mathrm{e}}$, and Michelle M. Wiest ${ }^{\mathrm{f}}$ 


\section{Abstract}

37 Invasions by non-native plants can alter ecosystems such that new ecological states are reached,

38 but less is known about how these transitions influence animal populations. Sagebrush

39 (Artemisia tridentata) ecosystems are experiencing state changes because of fire and invasion by exotic annual grasses. Our goal was to study the effects of these state changes on the Owyhee

41 and western harvester ants (Pogonomyrmex salinus Olsen and P. occidentalis Cresson,

42 respectively). We sampled 358 1-ha plots across the northern Great Basin, which captured

43 unburned and burned conditions across 1 to $\geq 31$ years post-fire. Our results indicated an

44 immediate and consistent change in vegetation states from shrubland to grassland between 1 and

4531 years post-fire. Harvester ant occupancy was unrelated to time since fire, whereas we

46 observed a positive effect of fire on nest density. Similarly, we discovered that fire and invasion

47 by exotic annuals were weak predictors of harvester ant occupancy, but strong predictors of nest

48 density. Occupancy of harvester ants was more likely in areas with finer-textured soils, low

49 precipitation, abundant native forbs, and low shrub cover. Nest density was higher in arid

50 locations that recently burned and exhibited abundant exotic annual and perennial (exotic and

51 native) grasses. Finally, we discovered that burned areas that received post-fire restoration had

52 minimal influence on harvester ant occupancy or nest density compared with burned and

53 untreated areas. These results suggest that fire-induced state changes from native shrublands to

54 grasslands dominated by non-native grasses have a positive effect on density of harvester ants

55 (but not occupancy), and that post-fire restoration does not appear to positively or negatively

56 affect harvester ants. Although wildfire and invasion by exotic annual grasses may negatively

57 affect other species, harvester ants may indeed be one of the few winners among a myriad of

58 losers linked to vegetation state changes within sagebrush ecosystems. 


\section{$59 \quad$ Keywords}

60 Biological invasions; Bromus tectorum; granivore; Pogonomyrmex; state transitions; wildfire 


\section{Introduction}

Biological invasions of non-native plants alter ecosystem processes, and thus impact native fauna in many direct and indirect ways (D'Antonio and Vitousek, 1992; White et al., 2006; Litt and Pearson, 2013). In some cases, non-native plants have altered ecosystems to such an extent that new, relatively stable ecological states are reached resulting in novel plant communities (Bestelmeyer et al., 2011). Ecological state transitions caused by non-native plants can directly change demographic rates of animals, such as survival or production, resulting in changes in occupancy and density (e.g., Ostoja et al., 2009; Ostoja and Schupp, 2009; Litt and Steidl, 2011). By altering population parameters of animals, particularly those with a disproportionate influence on the surrounding ecosystem, biological invasions of non-native plants can cause cascading or indirect effects that further alter animal-animal or plant-animal interactions (e.g., White et al., 2006). These indirect effects could ultimately influence the resilience of an ecosystem to recover from or resist future invasion by non-native species (e.g., Toro et al., 2015).

Sagebrush (Artemisia tridentata) ecosystems in lower elevations (i.e., A. t. wyomingensis) throughout western North America are experiencing changes in vegetation states because of a synergy between changing fire regimes and biological invasions by exotic annual grasses such as cheatgrass (Bromus tectorum; Baker, 2011; Davies et al., 2011; Miller et al., 2011; Chambers et al., 2014). Historically, sagebrush vegetation states were generally composed of shrublands with native perennial grasses as the dominant functional group within the sparsely vegetated understory (Miller et al., 2011). However, invasion by exotic annual grasses (due to human activity, land conversion, and grazing; Knick et al., 2011) has substantially changed fire regimes and resulted in lower fire return intervals, larger area burned per fire, and increased probability 
84 of fire (Baker, 2011; Miller et al., 2011; Balch et al., 2013). These changes in fire regimes have 85 subsequently enhanced the invasion of exotic annual grasses (Chambers et al., 2007). Remotely sensed data indicate that the extent of cheatgrass dominance exceeded $40,000 \mathrm{~km}^{2}$ of the Great

87 Basin Desert (nearly 10\%) in 2008 (Bradley and Mustard, 2008), and it has likely increased since then. Indeed, changes in wildfire and biological invasions by exotic annual grasses are synergistically contributing to current vegetation state changes in sagebrush ecosystems; that is, shifts from sagebrush shrublands with native perennial grasses to grasslands dominated by exotic

91 annual grasses (Davies et al., 2011; Miller et al., 2011; Chambers et al., 2014). To understand 92 the consequences of such changes, it is essential to evaluate how fire and exotic annual grasses influence functionally important animals within sagebrush landscapes.

94 Considering the extent and magnitude of state changes in sagebrush ecosystems, there are surprisingly few studies assessing the effects of these changes on animals. Previous work has demonstrated negative effects of cheatgrass invasion on communities of passerines (Knick et al.

97 1995, 2000), small mammals (Ostoja and Schupp, 2009; Rieder et al., 2010; Freeman et al., 2014), lizards (Newbold, 2005; Rieder et al., 2010), and snakes (Hall et al., 2009).

99 Contrastingly, Ostoja et al. (2009) documented an increase in density of ant assemblages in areas 100 dominated by cheatgrass. Although this information enhances our understanding of how state 101 changes influence animals, most of the previous studies 1) were limited in spatial extent (e.g., $102 \leq 25-400 \mathrm{~km}^{2}$ ), 2) were unable to assess how plant and animal parameters change as a function of 103 recovery time (e.g., time since fire or invasion), and 3) could not adequately assess the relative 104 importance of state changes in the context of other environmental gradients. Therefore, our aim 105 was to assess state changes in a sagebrush ecosystem and evaluate the effects on occupancy and 106 density of harvester ants across an extensive spatial gradient capturing a range of time since fire. 
P. occidentalis Cresson, hereafter harvester ant) as target species because they are granivorous and also serve as ecosystem engineers (e.g., Jones et al., 1994; 1997; 2010) in many desert environments (MacMahon et al., 2000). In arid ecosystems seed predation and movement are 111 arguably the most critical plant-animal interactions shaping plant communities (e.g., Brown et 112 al., 1979; Crist and MacMahon, 1992; Heske et al., 1993). Pearson et al. (2014) indicated that 113 harvester ants in Argentina suppressed plant recruitment by 22-89\%. Further, harvester ant 114 activities directly and indirectly influence plant communities by removing vegetation (Carlson 115 and Whitford, 1991; Gosselin et al. 2016), and increasing soil nutrients and water absorption 116 (Mandel and Sorenson, 1982; Blom, 1990; Wagner et al., 1997; Wilby et al., 2001; Brown et al., 117 2012). The trophic and ecosystem engineering interactions associated with harvester ants 118 emphasizes the importance of evaluating how state changes influence their occupancy and 119 density.

120 Our research objectives were to 1) assess state changes in vegetation, occupancy of 121 harvest ants, and nest density of harvester ants (hereafter density) across a gradient of time since 122 fire, 2) determine the relative importance of fire and biological invasions on harvester ants, and 123 3) assess the effect of post-fire restoration on harvester ants. We expected state changes from 124 shrublands to exotic annual grasslands would happen immediately after fire (i.e., 1 year post-fire) 125 and remain for all years across our post-fire gradient (e.g., Baker, 2011), and that these changes 126 would have positive effects on occupancy and density of harvester ants (Ostoja et al., 2009). We 127 also predicted that the relative importance of fire and exotic annual grasses would be greater for 128 harvester ant density compared to occupancy, and that the effects of both factors would be 129 positive. We expected this pattern because evidence indicates that biotic gradients largely 
130 influence variation in density, while abiotic gradients tend to drive variation in occupancy (e.g.,

131 Boulangeat et al., 2012; Holbrook et al., in press). Lastly, we expected areas with evidence of

132 post-fire restoration (e.g., rows of native or exotic perennial grasses) that suppressed cheatgrass

133 to have little effect or a slight negative effect on harvester ants relative to burned and untreated

134 areas because of the positive effect of exotic annual grasses on harvester ants (Ostoja et al.,

135 2009). Collectively, this work contributes to the understanding of vegetation state changes

136 within sagebrush ecosystems as well as advances our understanding of the consequences of such

137 changes on the animal community.

\section{Methods}

140 Study area and sampling

141 We conducted this study across a $\sim 78,400 \mathrm{~km}^{2}$ extent within publicly managed sagebrush

142 areas throughout southern Idaho and Oregon, USA (Figure 1). To capture a gradient of

143 vegetation states we combined existing data sets from three separate studies of post-wildfire and

144 seeding treatments (one study took place in 2008-2009, and the second was conducted in 2013-

145 2014). In each study, plant community data and colony density of harvester ants were recorded

146 using identical methods at locations that were selected randomly within each study area (i.e.,

147 southeastern Oregon and southwestern Idaho). We used GIS to randomly place 1-ha plots

148 within: 1) areas that were previously burned and seeded (via aerial or rangeland drill methods by

149 the U.S. Bureau of Land Management) with native and exotic perennial plants, 2) areas that were

150 burned and not seeded, and 3) areas that have not burned for at least the last $\sim 33$ years. Post-fire

151 seeding treatment characteristics were derived from the Land Treatment Digital Library (Pilliod

152 and Welty 2013). The sample size from the 2008-2009 and 2013-2014 study were 225 and 133, 
153 respectively, with an allocation of 20-42\% burned, 28-39\% burned and treated, and 27-39\%

154 unburned. Sites ranged in mean annual precipitation from 20-64 cm and fire years ranged from

155 1980-2012. The dominant plant communities we sampled include big sagebrush, winterfat

156 (Krascheninnikovia lanata), shadscale saltbrush (Atriplex confertifolia), Sandberg bluegrass

157 (Poa secunda), and cheatgrass.

Harvester ant data

At each 1-ha plot, we surveyed for harvester ant nests during April-August in 2008-2009

or 2013-2014. Our sampling season was coincident with harvester ant activity, allowing us to

162 identify active nests or colonies. To characterize harvester ant occupancy and colony density

163 during 2008-2009, we enumerated colonies within three $100 \mathrm{~m} \times 2 \mathrm{~m}\left(600 \mathrm{~m}^{2}\right)$ belt-transects

164 spaced $25 \mathrm{~m}$ apart. During 2013-2014, we increased our survey effort to three $100 \times 4 \mathrm{~m}(1200$

$165 \mathrm{~m}^{2}$ ) belt-transects because of relatively low ant densities at sites sampled during this time. A

166 three transect design was an appropriate balance of statistical precision and sampling effort

167 (Holbrook et al., 2015). We classified a nest as active if we observed individual ants in or on the

168 nest. If no individuals were detected, observers disturbed the nest and waited for up to 30

169 seconds to solicit a response. Previous analyses indicated high correlation (i.e., $r=0.99$, slope $=$

170 1.01) of counts of harvester ant colonies between independent observers, which was indicative of

171 high survey consistency and detection probabilities (see Holbrook et al., 2015). Finally, we

172 resampled 30 plots in 2014 that we surveyed in 2013 to assess interannual variation in the

173 density of harvester ant colonies. Total counts of ant colonies were similar between years, as

174 indicated by the Pearson's correlation coefficient $(r=0.95)$, suggesting little annual turnover in

175 ant colonies. 


\section{Time since fire and vegetation data}

We used GIS and field data to characterize time since fire (Table 1). First, we overlapped 179 a fire perimeter geodatabase (USGS, unpublished data), over our 1-ha plots to determine the most recent fire $(\geq 1980)$ intersecting each plot. We limited our analyses to $\geq 1980$ because fire

181 information before 1980 is unreliable (Miller et al. 2011). We then used field data to validate if 182 the plot exhibited characteristics of a burn (i.e., few or no shrubs present; Chambers et al. 2014), 183 but was not seeded (i.e., lack of regularly spaced rows of exotic or perennial grasses); these plots 184 were classified as "burned" and were assigned a time since fire value. We then used all plots 185 with no evidence of fire (i.e., containing a spatially consistent shrub component) as our controls 186 characterizing unburned conditions. This grouping of plots $(n=210)$ was used to satisfy our first 187 objective of assessing responses of vegetation and harvester ants across a gradient of time since 188 fire (without the influence of management such as post-fire seeding). Next, to satisfy our second 189 objective we assigned the appropriate time since fire value to "burned and treated" plots, as well 190 as assigned a value to "unburned" plots $(n=337)$. We classified plots as "burned and treated" if 191 they fell within known post-fire seeding areas and/or exhibited evidence of successful seeding, 192 such as rows of native or exotic perennial grasses. For our unburned plots, we conservatively 193 assigned the maximum value (e.g., 33 years) of time since fire by subtracting the survey year 194 from 1980. If we did not assign our unburned plots with a time since fire value we would have 195 not been able to assess the relative importance of shrub cover and all other covariates on 196 harvester ant occupancy or colony density, which was a major component of our second 197 objective. 
We characterized the vegetation community at each plot using a sample of 6-9 random or systematically placed (depending on the study site) locations within our plots. At each location, we captured a nadir (i.e., $90^{\circ}$ ) photograph from $2 \mathrm{~m}$ above the ground (Pilliod and Arkle, 2013).

201 This height corresponded to a $1.5 \times 2 \mathrm{~m}$ area of ground surface and provided sufficient height 202 above shrubs. We used SamplePoint 1.43 software (Booth et al., 2006) to measure the cover of 203 species and abiotic habitat components (e.g., rock, soil, litter) at 100 computer-selected pixels 204 per image. We classified each pixel to a plant group (Table 1), which generated a percent cover 205 measurement at each photographed location. We then averaged percentages across the 6-9 206 locations to attain plot-level estimates of percent cover.

\section{Other environmental data}

We developed an abiotic soil index describing soil texture using STATSGO data (Table map key at each plot, and averaged (across up to 10 soil names) the proportion of soil passing

212 through a number 4 sieve at the first soil depth. This resulted in an index with larger numbers 213 indicating finer-grained soils, and low numbers indicating coarse-grained soils. We expected 214 harvester ants to be strongly associated with finer-grained soils (e.g., Johnson, 1992) because 215 they retain soil moisture better than coarse-grained soils (Johnson, 2001). Soil moisture 216 positively influences 1$)$ survival of harvester ant (P. rugosus, $P$. barbatus) foundresses, 2) wet 217 body mass, and 3) brood production during colony establishment and growth (Johnson, 1998), 218 which are the most vulnerable life stages for colonies.

We used GIS databases to generate climate metrics at each plot (Table 1). First, we 
221 Regressions on Independent Slopes Model (PRISM Climate Group, Oregon State University

222 2004) during the time period 1979-2008. We expected harvester ants to be negatively associated

223 with mean annual precipitation (over our sampled gradient) because harvester ants are

224 evolutionarily adapted for semi-arid or arid environments (Johnson, 2001) and tend to be more

225 abundant in these locations (Hanser et al., 2011).

226

227 Data analysis

228

State Changes

229

To assess the direction and temporal trend in plant characteristics and occupancy and

230 colony density of harvester ants, we categorized plots according to quantiles of the time since

231 fire distribution. Our categories allowed us to maintain reasonable sample sizes within each bin

232 of time since fire, which resulted in 1-6 years $(n=32), 7-21$ years $(n=26), 21-31$ years $(n=29)$,

233 and unburned $(n=123)$. We used our unburned group as our control under the assumption that it

234 closely matched the pre-burn vegetation state. We elected to bin data across our time since fire

235 gradient because we anticipated nonlinear plant responses. At each bin, we computed the mean

$236( \pm 90 \% \mathrm{CI})$ for exotic annual grasses (EAG), native perennial grasses (NPG), and shrubs, as well

237 as proportion of sites occupied and density of harvester ant colonies. We focused on these plant

238 groups because they are the major groups discussed in terms of vegetation state changes in

239 sagebrush ecosystems (e.g., Chambers et al., 2014), and they were the most dominant groups in 240 our data (see Table 1).

241

242

Relative Importance of Fire and Biological Invasions 
To evaluate the relative importance of fire and biological invasions on harvester ant

244 occupancy and colony density, we combined vegetation data, time since fire, and other

245 environmental factors potentially important for harvester ants (see Table 1) into generalized

246 linear models. We used a nested approach similar to Boulangeat et al. (2012) and Holbrook et al.

247 (in press), within which we built one model assessing the variation in occupancy $(n=337)$, and

248 then built a second model to evaluate variation in colony density $(n=162)$ for those plots that

249 were occupied. We used generalized linear models with a binomial distribution for occupancy

250 data, and a negative binomial error distribution for density data. In each model, we included an

251 offset describing the difference in areas surveyed among study sites to account for differences in

252 survey effort (i.e., 600 vs. $1200 \mathrm{~m}^{2}$ ). Our research objectives were focused on general patterns,

253 thus, we evaluated only main effects.

Prior to model development, we standardized covariates and evaluated multicollinearity.

255 We standardized continuous covariates by $\left(x_{i}-\bar{x}\right) /(2 \times \sigma)$ where $x_{i}$ equals an observation at

256 plot $i, \sigma$ is the standard deviation of covariate $x$, and $\bar{x}$ is the mean of the covariate. This

257 standardization allowed for an equal comparison among effect sizes for continuous and binary

258 covariates (Gelman, 2008), which was important for our objective of assessing relative

259 importance of fire and biological invasions. We assessed collinearity among covariates, and

260 removed temperature because it was correlated with precipitation $(r=-0.67)$.

261

For each response variable, we developed an initial model with all covariates except

262 exotic annual grasses and time since fire (see Table 1). For these analyses, we kept the

263 continuous scale of time since fire because we expected linear responses by harvester ants. We

264 then added both exotic annual grasses and time since fire to the initial model, and tested the 
265 drop-in-deviance using a likelihood ratio test to evaluate if exotic annual grasses and time since

266 fire increased the fit of our model. For example,

267 Initial model:

268 logit or $\log \left(Y_{i}\right)=\beta_{0}+\beta_{1}\left(x_{i 1}\right)+\beta_{2}\left(x_{i 2}\right)+\beta_{3}\left(x_{i 3}\right)+\varepsilon$

269 Fire and biological invasion model:

270 logit or $\log \left(Y_{i}\right)=\beta_{0}+\beta_{1}\left(x_{i 1}\right)+\beta_{2}\left(x_{i 2}\right)+\beta_{3}\left(x_{i 3}\right)+\beta_{4}\left(T S F_{i}\right)+\beta_{4}\left(E A G_{i}\right)+\varepsilon$

where $Y=$ response variable at plot $i, \beta=$ regression coefficient associated with a

272 particular covariate, and $x=$ observation of a particular covariate at plot $i$. As aforementioned, to

273 provide a conservative estimate of time since fire in unburned plots, we set time since fire to the

274 maximum values based on fire data from $\geq 1980$.

275

We assessed model fit for our most supported (i.e., either model [1] or [2], depending on

276 results) occupancy and density models. For our occupancy model, we tested goodness-of-fit

277 (Hosmer and Lemeshow, 2000) and assessed predictive performance by calculating the area

278 under the curve (AUC) of a receiver operating characteristic (ROC; Robin et al., 2011). A ROC

279 plot characterizes true positives against false positives, and the AUC ranges from 0-1 providing a

280 measures of the model's ability to correctly discriminate between plots that are occupied versus

281 unoccupied (Hosmer and Lemeshow, 2000; Robin et al., 2011). An AUC of 0.5 indicates

282 random discrimination, whereas values greater than 0.5 indicate progressively better

283 discrimination (Hosmer and Lemeshow, 2000). For our density model, we computed the

284 Spearman's rank correlation coefficient between the observed and predicted counts as a measure

285 of fit. Finally, we plotted the effect sizes $( \pm 90 \% \mathrm{CI})$ of the estimated parameters describing

286 covariate relationships, which allowed us to assess statistical significance (i.e., different from 0)

287 as well as determine the effects that were the strongest. To complete these analyses, we used 
288 program R (R Core Team 2015) and packages 'MASS' (Venables and Ripley, 2002),

289 'ResourceSelection' (Lele et al., 2014), and 'pROC' (Robin et al., 2011).

\section{Effects of Post-Fire Restoration}

We assessed if post-fire seeding had an effect on occupancy and colony density of

293 harvester ants that was statistically different than burned plots that were not treated. To

294 characterize the vegetation conditions among burned $(n=98)$ and burned and treated $(n=124)$,

295 we computed the mean $( \pm 90 \% \mathrm{CI})$ for the plant groups aforementioned (i.e., exotic annual

296 grasses, native perennial grasses, and shrubs). We also included the unburned category $(n=123)$

297 for comparative purposes. We then calculated the proportion of sites occupied and density of

298 harvester ant colonies among groups to evaluate statistical differences.

300 Results

301 State Changes

Across our sample, we observed 0-2.8 harvester ant colonies per $100 \mathrm{~m}^{2}$, and $48 \%$ of the

303358 plots we surveyed were occupied by ants. The effect of time since fire on shrub cover was

304 immediate and consistent in that the estimated shrub cover for years 1-31 post-fire was similar $305(<4 \%)$ and significantly less than shrub cover in unburned areas (14\%; Figure 2). Of our total 306 sample, $64 \%$ of plots experienced this state change from shrublands to grasslands (i.e., sites that

307 were burned). Additionally, native perennial grasses increased between 1-21 years (12-17\%) and 308 22-31 years (32\%) post-fire, and the estimate for 22-31 years was similar to unburned areas 309 (Figure 2). Cover of exotic annual grasses was highest during 1-21 years post-fire (47-51\%), but 310 was significantly lower 22-31 years post-fire (23\%) and in unburned areas (12\%; Figure 2). 
311 Collectively, these results indicate that shrub cover was removed after fire and did not recover up

312 to 31 years post-fire; however, exotic annual grasses decreased and native perennial grasses

313 increased over time, but this pattern was entirely contingent on the bin of 22-31 years post-fire.

314 Occupancy and colony density of harvester ants displayed disparate patterns across our

315 time since fire gradient. The proportion of plots occupied by harvester ants was unrelated to

316 time since fire (Figure 2). However, colony density was statistically higher in areas that burned

317 compared to unburned conditions (Figure 2). In addition, we observed a decrease in colony

318 density as time since fire increased, which highlighted a positive effect of recent fire (Figure 2).

\section{Relative Importance of Fire and Biological Invasions}

321 Our modeling results indicated that biological invasions by exotic annual grasses and the

322 effect of time since fire did not improve model fit for occupancy $\left(X^{2}=4.33, \mathrm{df}=2, p=0.12\right)$ of

323 harvester ants, but it did improve fit for density $\left(X^{2}=15.79\right.$, df $\left.=2, p<0.01\right)$. Thus, we

324 continued analyses with our reduced model for characterizing occupancy of harvester ants, but

325 used the biological invasion and fire model for characterizing density. For our occupancy model,

326 the goodness-of-fit test indicated appropriate fit $\left(X^{2}=21.4, \mathrm{df}=15, p=0.13\right)$, and predictive

327 performance was high $(\mathrm{AUC}=0.91)$. Our density model suggested reasonable model fit as

328 measured by Spearman's rank correlation coefficient $(\rho=0.60)$.

329 The strongest positive effect size we observed in our occupancy model was associated

330 with soil texture, and the strongest negative effect was associated with precipitation (Figure 3).

331 These results indicated that harvester ant occupancy was positively influenced by finer-grained

332 soils and drier locations across our sampling extent. Next, we observed a relatively strong and 
333 positive effect of native forbs on harvester ant occupancy, followed by a comparatively weak and 334 negative effect of shrub cover. All other effects were insignificant.

335 Similar to our occupancy model, our strongest (and negative) effect from our density

336 model was associated with precipitation, reinforcing the positive effect of relatively drier locales

337 on harvester ants (Figure 3). In contrast, however, we observed a positive and significant effect

338 of exotic annual grasses and a negative effect of time since fire, indicating a positive effect of

339 increasing exotic annual grasses and recent fires. This was consistent with the patterns we

340 observed when evaluating differences among vegetation and colony density across the time since

341 fire gradient (Figure 2). We also documented a positive effect of native and exotic perennial

342 grasses on colony density, suggesting an increase in harvester ants in areas with more perennial

343 grasses. We observed no effect of soil texture, native forbs, or shrub cover on density of ant

344 colonies, which contrasted with our occupancy results. Similarly, we discovered no effect of

345 exotic forbs.

346

347 Effects of Post-Fire Restoration

348 Lastly, we found no evidence that the vegetation conditions created by post-fire seeding

349 (i.e., burned and treated) generated a response in harvester ants that was different than burned

350 areas that had not been seeded (Figure 4). We did, however, document patterns similar to our

351 previous results highlighting that a reduction in shrubs was associated with occupancy and

352 higher densities of harvester ants.

353

354 Discussion 
Our results suggest that fire is indeed changing vegetation states from what were

356 historically shrublands to native perennial or exotic annual grasslands, and that this process is

357 spatially extensive (e.g., 64\% of our sample experienced this state change). Density of harvester

358 ant colonies was positively associated with state changes, whereas occupancy of harvester ants

359 appears to be driven primarily by abiotic gradients such as climate and soil-texture rather than

360 effects of fire or state changes. Overall, our work contributes to the understanding of fire-

361 induced state changes within sagebrush ecosystems, and emphasizes the importance of assessing

362 how those changes influence both occupancy and density of animals to gain a better

363 understanding of the relative effects of environmental change on organisms.

364

365 State Changes

366 Similar to previous work in sagebrush ecosystems (e.g., Baker, 2011), we quantitatively

367 documented an immediate (i.e., 1 year post-fire) and relatively consistent change from

368 shrublands to grasslands that persisted for at least 31 years after fire. Consistent with predictions

369 (Miller et al., 2011), we found that exotic annual grasses were the dominant vegetation state 1-21

370 years post-fire. In addition, the abundance of exotic annual grasses was higher than unburned

371 conditions up to 31 years post-fire, which highlights the long-term consequences of fire in

372 Wyoming big sagebrush habitats (Chambers et al. 2014). Finally, native perennial grasses

373 increased over time since fire such that they were similar to exotic annual grasses 22-31 years

374 post-fire (Figure 2). However, as aforementioned (see Results), the increase in native perennial

375 grasses, as well as the decrease in exotic annual grasses, was entirely dependent on the bin of 22-

37631 years post-fire. Therefore, we post-hoc examined the composition of the sample within 22-31

377 years post-fire (as well as the other bins of time since fire). Although the composition of the 
378 sample was nearly equal across our larger study areas, a subset of plots receiving more average 379 precipitation (e.g., $\sim 45 \mathrm{~cm}$ versus $\sim 25 \mathrm{~cm}$ ) was disproportionately driving the patterns for exotic 380 annual and native perennial grasses in the bin of 22-31 years post-fire. When only including 381 sites with lower precipitation, cover of exotic annual grasses was higher than native perennial 382 grasses 22-31 years post-fire. Thus, similar to previous studies (e.g., Chambers et al. 2014), our 383 data suggest that areas within big sagebrush communities that receive lower amounts of 384 precipitation exhibit less recovery potential (in terms of native perennials increasing after fire 385 and exotic annuals decreasing) than areas receiving higher amounts of precipitation.

We expected both occupancy and density of harvester ants to be positively associated 387 with state changes (e.g., Ostoja et al., 2009), but we only observed a pattern consistent with our 388 predictions in density of harvester ant colonies (Figure 2). This pattern suggested that high 389 densities of harvester ants were associated with fire and exotic annual grasses, but the relative 390 influence of each of these factors was unclear. Previous work has indicated much higher 391 densities of harvester ants in areas that are dominated by exotic annual grasses (Ostoja et al., 392 2009; Gosselin et al., 2016). Although harvester ants generally do not prefer cheatgrass seeds 393 (Crist and MacMahon, 1992; Ostoja et al. 2013), our data are consistent with the hypothesis that 394 cheatgrass and other exotic annuals could provide an abundant food resource for harvester ants 395 that may support high colony densities. However, other indirect mechanisms, such as 396 competitive or predatory release (e.g., Rodriguez, 2006; White et al., 2006; Ostoja et al., 2009) 397 or increased solar radiation and access to deep soil moisture (Wight and Nichols, 1966; Bucy and 398 Breed, 2006), could be contributing to the positive response we observed between harvester ants 399 and fire and/or exotic annual grasses. Additional data are needed to disentangle the underlying 
400 direct and indirect mechanisms of the positive relationship between harvester ants and state

401 changes in sagebrush habitats.

402

403

404

405

406

407

408

409

410

411

412 substantiating previous analyses indicating a biogeographical affinity and evolutionary

413 adaptations of harvester ants for arid locations (e.g., Johnson, 2001; Hanser et al., 2011). We

414 predicted a positive effect of perennial (exotic and native) grasses and (as aforementioned) exotic

415 annual grasses because of production of preferred and abundant seed resources, respectively

416 (Crist and MacMahon, 1992; Ostoja et al., 2013). Finally, a negative effect of time since fire on

417 density of harvester ant colonies (indicating an increase in colony density for years immediately

418 post-fire) was expected because fires reduce shrub and other surface cover, and consequently

419 increase availability of potential nest and foraging sites (e.g., Zimmer and Parmenter, 1998;

420 Ratchford et al., 2005; Arnan et al., 2006; Matsuda et al., 2011). The occurrence of fire might

421 indeed trigger a colonization response from harvester ants because of a spike in resource (e.g.,

422 food and nest sites) availability. 
In contrast, variation in harvester ant occupancy was best explained by precipitation, soil

424 texture, and native forbs; although, effects of shrub cover and exotic perennial grasses were

425 significant. The negative effect of precipitation, which was stronger for occupancy compared to

426 density, further substantiated the affinity of harvester ants for arid locations (Johnson, 2001).

427 Additionally, the positive effect of finer-grained soils on occupancy was expected because they

428 retain soil moisture better than coarse-grained soils, and soil moisture is related to foundress

429 survival and brood production (Johnson, 1998; Johnson, 2001). The negative effect of shrub

430 cover was consistent with our general predictions in that shrubs may limit nest site locations or

431 inhibit food availability through competition with grasses. Lastly, we observed a positive effect

432 of native forbs and exotic perennial grasses. Native forb species in our study area, such as

433 slickspot peppergrass (Lepidium papilliferum), provide fruits and seeds that harvester ants gather

434 in large quantities when present, consistent with a positive effect of native forbs on occupancy of

435 harvester ants (White and Robertson, 2009). Similarly, exotic perennials are often abundant in

436 areas seeded after fire (Knutson et al. 2014), and may provide an abundant seed source for

437 harvester ants (Gosselin et al. 2016).

438 Combining our occupancy and density results from our generalized linear models, we

439 observed that effect sizes for a particular variable changed depending on the response, and the

440 changes were generally consistent with predictions derived from ecological theory. For example,

441 many authors have provided evidence that broader scale environmental gradients better predict

442 variation in occupancy patterns, whereas local level dynamics better explain variation in density

443 (e.g., Soberón, 2007; Wiens, 2011; Boulangeat et al., 2012; Holbrook et al., in press). Indeed,

444 our data contribute to the weight of evidence suggesting that different environmental factors

445 have disproportionate effects on variation in occupancy and density, and emphasize the 
446 importance of testing alternative hypotheses concerning each factor. These multi-level

447 approaches provide a more complete understanding of how animals are affected by landscape

448 change, which can be directly applied for more precise management actions (Ehrlén and Morris, 449 2015).

450

$451 \quad$ Implications

To our knowledge, our work is among the first to evaluate the relative influence of state

453 changes along a time since fire gradient on both occupancy and density of animals in sagebrush

454 ecosystems. We demonstrated that fire-induced changes from shrublands to grasslands are

455 strong predictors of density (but not occupancy) of an important desert granivore, harvester ants.

456 Land managers throughout the sagebrush ecosystem are highly concerned with the conversion

457 from native shrublands and grasslands to exotic annual grasslands, and consequently are

458 implementing large-scale restoration efforts that cost millions of dollars per year (Epanchin-Niell

459 et al., 2009). We found no evidence that occupancy or density of harvester ants are responding

460 to these restoration efforts (Figure 4), although, previous work indicates that other animals (e.g.,

461 Piute ground squirrels; Urocitellus mollis) are indeed benefiting from post-fire rehabilitation and

462 restoration (Holbrook et al., in press). Extending the assessment of how restoration influences

463 the animal community within sagebrush ecosystems will provide a more refined understanding

464 of the expected benefits and costs associated with the vast and expensive restoration efforts

465 currently being conducted.

466 As with many environmental changes, such as state changes or restoration activities,

467 there will be winners and losers (e.g., Knick et al., 2014). In our context, it appears density of

468 harvester ant colonies will likely continue to increase following more drought, expansion of 
exotic annual grasses, and increased wildfire in the Great Basin (Abatzoglou and Kolden, 2012;

470 Cook et al., 2015), while occupancy may be relatively independent of these changes. This

471 suggests that harvester ants are likely winners considering the large-scale state changes within

472 sagebrush ecosystems, which might be somewhat advantageous for restoration efforts. For

473 example, because harvester ants harvest cheatgrass seeds (Ostoja et al., 2013) and can reduce

474 cheatgrass cover and increase native bunchgrasses near their nests (Gosselin et al., 2016), they

475 may help delay the transition from native grasslands to exotic annual grasslands in some

476 locations by removing or reducing seed sources. This hypothesis is consistent with previous

477 work highlighting that granivores can be an important component of biological resistance to

478 exotic plant invasions (e.g., Nuñez et al., 2008; Pearson et al., 2011; Pearson et al., 2014). The

479 potential of harvester ants to inhibit plant invasions may be increasingly facilitated given that

480 occupancy of harvester ants was independent of state changes, and thus ants could occupy many

481 locations across a landscape and take advantage of those areas that begin to experience state

482 changes. Alternatively, however, previous work has also indicated apparent competition

483 between native and exotic grasses mediated by granivores (Orrock et al., 2008), whereby seed

484 consumption of the native species increased with increasing presence of the exotic species.

485 Additional work assessing the role of granivores in reducing or facilitating biological invasions

486 would provide unique opportunities for restoration ecologists to incorporate the ecological roles

487 of animals into their restoration plans to help achieve objectives (sensu Byers et al., 2006).

488 Collectively, our work represents a unique assessment of how state changes within the sagebrush 489 ecosystem are positively influencing an aridland granivore, the harvester ant, which may result in 490 indirect effects that influence future conservation or restoration efforts. 


\section{Acknowledgments}

493

JDH is sincerely thankful for D. Holbrook's consistent willingness to help his son with

494 field work. This work was supported by the National Science Foundation's IGERT program

495 (Award 0903479), Shikar Safari Club International Scholarship, the J. Michael and Sharon L.

496 Scott Graduate Student Scholarship, Joint Fire Science Program (Project ID: 11-1-2-30), and the

497 USGS Coordinated Sagebrush Studies Project. We thank S. Knick, J. McIver, and two

498 anonymous reviewers for providing insightful comments that greatly improved this manuscript.

499 Any use of trade names is for descriptive purposes only and does not imply endorsement by the

500 U.S. government.

501 


\section{References}

Abatzoglou, J.T., Kolden, C.A., 2011. Climate change in western US deserts: potential for increased wildfire and invasive annual grass. Rangeland Ecol. Manage. 64, 471-478.

Arnan, X., Rodrigo, A., Retana. J., 2006. Post-fire recovery of Mediterranean ground ant communities follows vegetation and dryness gradients. J. Biogeogr. 33, 1246-1258.

Baker, W.L., 2011. Pre-Euro-American and recent fire in sagebrush ecosystems, in Knick, S., Connelly, J. (Eds.), Greater Sage-Grouse: Ecology and Conservation of a Landscape Species and its Habitats. Studies in Avian Biology, University of California Press, California, pp. 185-201.

Balch, J.K., Bradley, B.A., D’Antonio, C.M., Gómez-Dans, J., 2013. Introduced annual grass increases regional fire activity across the arid western USA (1980-2009). Glob. Chang. Biol. 19, 173-183.

Bestelmeyer, B.T., Ellison, A.M., Fraser, W.R., Gorman, K.B., Holbrook, S.J., Laney, C.M., Ohman, M.D., Peters, D., Pillsbury, F.C., Rassweiler, A., Schmitt, R.J., Sharma, S., 2011. Analysis of abrupt transitions in ecological systems. Ecosphere 2, 129.

Byers, J.E., Cuddington, K., Jones, C.G., Talley, T.S., Hastings, A., Lambrinos, J.G., Crooks, J.A., Wilson, W.G., 2006. Using ecosystem engineers to restore ecological systems. Trends Ecol. Evol. 21, 493-500.

Blom, P., 1990. Potential impacts on radioactive waste disposal situations by the harvester ant, Pogonomyrmex salinus Olsen (Hymenoptera: Formicidae). M.S. thesis. University of Idaho, Moscow, Idaho, USA.

Booth, D. T., Cox, S.E., Berryman, R.D., 2006. Point sampling digital imagery with “Samplepoint.” Environ. Monit. Assess. 123, 97-108. 
Boulangeat, I., Gravel, D., Thuiller, W., 2012. Accounting for dispersal and biotic interactions to disentangle the drivers of species distributions and their abundances. Ecol. Lett. 15, 584593.

Bradley, B.A., Mustard, J.F., 2008. Comparison of phenology trend by land cover class: a case study in the Great Basin, USA. Glob. Chang. Biol. 14, 334-346.

Brown, G., Scherber, C., Ramos, P., Ebrahim, E.K., 2012. The effects of harvester ant (Messor ebeninus Forel) nests on vegetation and soil properties in a desert dwarf shrub community in north-eastern Arabia. Flora 207, 503-511.

Brown, J.H., Reichman, O.J., Davidson, D.W., 1979. Granivory in desert ecosystems. Annu. Rev. Ecol. Syst. 10, 201-227.

Bucy, A.M., Breed, M.D., 2006. Thermoregulatory trade-offs result from vegetation removal by a harvester ant. Ecol. Entomol. 31, 423-429.

Carlson, S.R., Whitford, W.G., 1991. Ant mound influence on vegetation and soils in a semiarid mountain ecosystem. Am. Midl. Nat. 126, 125-139.

Chambers, J.C., Roundy, B.A., Blank, R.R., Meyer, S.E., Whittaker, A., 2007. What makes Great Basin sagebrush ecosystems invasible by Bromus tectorum? Ecol. Monogr. 77, 117-145.

Chambers, J.C., Miller, R.F., Board, D.I., Pyke, D.A., Roundy, B.A., Grace, J.B., Schupp, E.W., and Tausch, R.J., 2014. Resilience and resistance of sagebrush ecosystems: implications for state and transition models and management treatments. Rangeland Ecol. Manage. 67, 440-454.

Cook, B.I., Ault, T.R., Smerdon, J.E., 2015. Unprecedented $21^{\text {st }}$ century drought risk in the American southwest and central plains. Science Advances 1, e1400082. 
Crist, T.O., MacMahon, J.A., 1992. Harvester ant foraging and shrub-steppe seeds: interactions of seed resources and seed use. Ecology 73, 1768-1779.

D’Antonio, C.M., Vitousek, P.M., 1992. Biological invasions by exotic grasses, the grass/fire cycle, and global change. Annu. Rev. Ecol. Syst. 23, 63-87.

Davies, K.W., Boyd, C.S., Beck, J.L., Bates, J.D., Svejcar, T.J., Gregg, M.A., 2011. Saving the sagebrush sea: an ecosystem conservation plan for big sagebrush plant communities. Biol. Conserv. 144, 2573-2584.

Ehrlén, J., Morris, W., 2015. Predicting changes in the distribution and abundance of species under environmental change. Ecol. Lett. 18, 303-314.

Epanchin-Niell, R., Englin, J., Nalle, D., 2009. Investing in rangeland restoration in the arid west, USA: countering the effects of an invasive weed on the long-term fire cycle. $\mathbf{J}$ Environ Manage, 91, 370-379.

Freeman, E.D., Sharp, T.R., Larson, R.T., Knight, R.N., Slater, S. J., McMillan, B.R., 2014. Negative effects of an exotic grass invasion on small-mammal communities. PLoS ONE 9, e108843.

Gelman, A., 2008. Scaling regression inputs by dividing by two standard deviations. Stat. Med. $27,2865-2873$.

Gosselin, E.N., Holbrook, J.D., Huggler, K., Brown, E., Vierling, K.T., Arkle, R.S., Pilliod, D.S., 2016. Ecosystem engineering of harvester ants: effects on vegetation in a sagebrushsteppe ecosystem. West. N. Am. Naturalist 76, 82-89.

Hall, L.K., Mull, J.F., Cavitt, J.F., 2009. Relationship between cheatgrass coverage and the relative abundance of snakes on Antelope Island, Utah. West. N. Am. Naturalist 69, 8895. 
571 Hanser, S.E., Leu, M., Aldridge, C.L., Nielsen, S.E., Rowland, M.M., Knick, S.T., 2011.

572 Occurrence and abundance of ants, reptiles, and mammals, in Hanser, S., Leu, M., Knick,

573 S.T., Aldridge, C.L. (Eds.), Sagebrush Ecosystem Conservation and Management:

574 Ecoregional Assessment Tools and Models for the Wyoming Basins. Allen Press,

$575 \quad$ Kansas, pp. 221-314.

576 Heske, E.J., Brown, J.H., Guo, Q., 1993. Effects of kangaroo rat exclusion on vegetation

577 structure and plant species diversity in the Chihuahuan desert. Oecologia 95, 520-524.

578 Holbrook, J.D., Arkle, R.S., Rachlow, J.L., Vierling, K.T., Pilliod, D.S., 2015. Sampling animal 579 sign in heterogeneous environments: how much is enough? J. Arid Environ. 199, 51-55.

Holbrook, J.D., Arkle, R.S., Rachlow, J.L., Vierling, K.T., Pilliod, D.S., Wiest, M.M., In Press. Occupancy and abundance of predator and prey: implications of the fire-cheatgrass cycle in sagebrush ecosystems. Ecosphere.

583 Hosmer, D.W., Lemeshow, S., 2000. Applied Logistic Regression, John Wiley and Sons, New 584 York.

Johnson, R.A., 1992. Soil texture as an influence on the distribution of the desert seed-harvester ants Pogonomyrmex rugosus and Messor pergandei. Oecologia 89, 118-124.

587 Johnson, R.A., 1998. Foundress survival and brood production in the desert seed-harvester ants $588 \quad$ Pogonomyrmex rugosus and P. barbatus (Hymenoptera, Formicidae). Insectes Sociaux 45, 255-266.

590 Johnson, R.A., 2001. Biogeoraphy and community structure of North American seed-harvester 591 ants. Annu. Rev. Entomol. 46, 1-29.

592 Jones, C.G., Lawton, J.H., Shachak, M., 1994. Organisms as ecosystem engineers. Oikos 69, 593 373-386. 
Jones, C.G., Lawton, J.H., Shachak, M., 1997. Positive and negative effects of organisms as physical ecosystem engineers. Ecology 78, 1946-1957.

Jones, C., Gutierrez, J., Byers, J., Crooks, J., Lambrinos, J., Talley, T., 2010. A framework for understanding physical ecosystem engineering by organisms. Oikos 12, 1862-1869.

Knick, S., Rotenberry, J., 1995. Landscape characteristics of fragmented shrubsteppe habitats and breeding passerine birds. Conserv. Biol. 9, 1059-1071.

Knick, S., Rotenberry, J., 2000. Ghosts of habitats past: contribution of landscape change to current habitats used by shrubland birds. Ecology 81:220-227.

Knick, S., Hanser, S., Miller, R., Pyke, D., Wisdom, M., Finn, S., Rinkes, E., Henny, C., 2011. Ecological influence and pathways of land use in the sagebrush, in Knick, S., Connelly, J. (Eds.), Greater Sage-Grouse: Ecology and Conservation of a Landscape Species and its Habitats. Studies in Avian Biology, University of California Press, California, pp. 203251.

Knick, S., Hanser, S., Leu, M., 2014. Ecological scale of bird community response to pinyonjuniper removal. Rangeland Ecol. Manage. 67, 553-562.

Knutson, K.C., Pyke, D.A., Wirth, T.A., Arkle, R.S., Pilliod, D.S., Brooks, M.L., Chambers, J.C., Grace, J.B., 2014. Long-term effects of seeding after wildfire on vegetation in Great Basin shrubland ecosystems. J Appl. Ecol. 51, 1414-1424.

Lele, S.R., Keim, J.L., Solymos, P., 2014. ResourceSelection: resource selection (probability) functions for use-availability data. R package version 0.2-4. http://CRAN.Rproject.org/package=ResourceSelection/ $($ accessed 01.04.15)

Litt, A.R., Pearson, D.E., 2013. Non-native plants and wildlife in the intermountain west. Wildl. Soc. Bull. 37, 517-526. 
617 Litt, A.R., Steidl, R.J., 2011. Interactive effects of fire and nonnative plants on small mammals in grasslands. Wildl. Monogr. 176, 1-31.

619 MacMahon, J.A., Mull, J.F., Crist, T.O., 2000. Harvester ants (Pogonomyrmex spp.): their 620 community and ecosystem influences. Annu. Rev. Ecol. Syst. 31, 265-291.

621 Mandel, R.D., Sorenson, C.J., 1982. The role of the western harvester ant (Pogonomyrmex 622 occidentalis) in soil formation. Soil Sci. Soci. Am. J. 46, 785-788.

623 Matsuda, T., Turschak, G., Brehme, C., Rochester, C., Mitrovich, M., Fisher, R., 2011. Effects 624 625 of local-scale wildfires on ground foraging ants (Hymenoptera: Formicidae) in southern California. Environ. Entomol. 40, 204-216.

626 Miller, R., Knick, S., Pyke, D., Meinke, C., Hanser, S., Wisdom, M., and Hild, A., 2011.

627 Characteristics of sagebrush habitats and limitations to long-term conservation, in Knick, 628 S., Connelly, J. (Eds.), Greater Sage-Grouse: Ecology and Conservation of a Landscape Species and its Habitats. Studies in Avian Biology, University of California Press, 630 California, pp. 145-184.

631 Newbold, T., 2005. Desert horned lizard (Phrynosoma platyrhinos) locomotor performance: the 632 influence of cheatgrass (Bromus tectorum). Southwest. Nat. 50, 17-23.

633 Nuñez, M.A., Simberloff, D., Relva, M.A., 2008. Seed predation as a barrier to alien conifer $634 \quad$ invasions. Biol. Invasions 10, 1389-1398.

635 Orrock, J.L., Witter, M.S., Reichman, O.J., 2008. Apparent competition with an exotic plant 636 reduces native plant establishment. Ecology 89, 1168-1174.

637 Ostoja, S.M., Schupp, E.W., 2009. Conversion of sagebrush shrublands to exotic annual 638 grasslands negatively impacts small mammal communities. Divers. Distrib. 5, 863-870. 
Ostoja, S.M., Schupp, E.W., Sivy, K., 2009. Ant assemblages in intact big sagebrush and converted cheatgrass-dominated habitats in Tooele County, Utah. West. N. Am. Naturalist 69, 223-234.

Ostoja, S.M., Schupp, E.W., Klinger, R., 2013. Seed harvesting by a generalist consumer is context dependent: interactive effects across multiple spatial scales. Oikos 122, 563-574.

Pearson, D.E., Icasatti, N.S., Hierro, J.L., Bird, B.J., 2014. Are local filters blind to provenance? Ant seed predation suppresses exotic plants more than natives. PLoS ONE 9, e103824.

Pearson, D.E., Callaway, R.M., Maron, J.L., 2011. Biotic resistance via granivory: establishment by invasive, naturalized, and native asters reflects generalist preference. Ecology 92, 1748-1757.

Pilliod D.S., Arkle. R.S., 2013. Performance of quantitative vegetation sampling methods across gradients of cover in Great Basin plant communities. Rangeland Ecol. Manage. 66, 634647.

Pilliod, D.S., Welty, J.L., 2013. Land Treatment Digital Library: U.S. Geological Survey Data Series 806. http://ltdl.wr.usgs.gov/ (accessed 01.01.2007)

PRISM Climate Group, Oregon State University, 2004. http://prism.oregonstate.edu/ (accessed 01.04.15).

R Core Team, 2015. R: a language and environment for statistical computing. R Foundation for Statistical Computing, Vienna, Austria. http://www.R-project.org/ (accessed 01.04.15).

Ratchford, J.S., Wittman, S.E., Jules, E.S., Ellison, A.M., Gotelli, N.J., Sanders, N.J., 2005. The effects of fire, local environment and time on ant assemblages in fens and forests. Divers. Distrib. 11, 487-497.

Rieder, J.P., Newbold, T., Ostoja, S.M., 2010. Structural changes in vegetation coincident with 

675 676 677 678

annual grass invasion negatively impacts sprint velocity of small vertebrates. Biol. Invasions 12, 2429-2439.

Robin, X., Turck, N., Hainard, A., Tiberti, N., Lisacek, F., Sanchez, J.C., Müler, M., 2011. pROC: an open-source package for $\mathrm{R}$ and $\mathrm{S}+$ to analyze and compare ROC curves. BMC Bioinformatics 12, 77 .

Rodriguez, L.F., 2006. Can invasive species facilitate native species? Evidence of how, when, and why these impacts occur. Biol. Invasions 8, 927-939.

Soberón, J., 2007. Grinnellian and Eltonian niches and geographic distributions of species. Ecol. Lett. 10, 1115-1123.

Soil Survey Staff, Natural Resource Conservation Service, United States Department of Agriculture. U.S. General Soil Map (STATSGO2). http://sdmdataaccess.nrcs.usda.gov/ (accessed 01.04.15).

Toro, I.D., Ribbons, R.R., Ellison, A.M., 2015. Ant-mediated ecosystem functions on a warmer planet: effects on soil movement, decomposition and nutrient cycling. J. Anim. Ecol. 84, 1233-1241.

Venables, W.N., Ripley, B.D., 2002. Modern applied statistics with S, fourth ed. Springer, New York.

Wagner, D., Brown, M., Gordon, D., 1997. Harvester ant nests, soil biota and soil chemistry. Oecologia 112, 232-236.

White, E.M., Wilson, J.C., Clarke, A.R., 2006. Biotic indirect effects: a neglected concept in invasion biology. Divers. Distrib. 12, 443-455.

White, J.P, Robertson, I., 2009. Intense seed predation by harvester ants on a rare mustard. Ecoscience 16, 508-513. 
685 Wight, J.R., Nichols, J.T., 1966. Effects of harvester ants on production of a saltbrush 686 community. J. Range Manage. 19, 68-71.

687 Wilby, A., Shachak, M., Boeken, B., 2001. Integration of ecosystem engineering and trophic 688 effects of herbivores. Oikos $92,436-444$.

689 Wiens, J.J., 2011. The niche, biogeography and species interactions. Philos. Trans. R. Soc. B $690 \quad 366,2336-2350$.

691 Zimmer, K., Parmenter, R.R., 1998. Harvester ants and fire in a desert grassland: ecological 692 responses of Pogonomyrmex rugosus (Hymenoptera: Formicidae) to experimental 693 wildfires in central New Mexico. Environ. Entomol. 27, 282-287. 
Table 1. Covariate descriptions, correlations, and collection methods for the variables used in analyses of vegetation states and harvester ant (Pogonomyrmex spp.) occupancy and density in Idaho and Oregon, USA.

\begin{tabular}{|c|c|c|c|c|}
\hline Variable & Units & Mean (Range) & Description & Method \\
\hline Soil & $\%$ & $85(62.5-98.25)$ & $\begin{array}{l}\text { Mean } \% \text { surface soil passing through a \#4 sieve } \\
\text { within each mukey code }\end{array}$ & $\begin{array}{l}\text { STATSGO } \\
(1: 250,000)\end{array}$ \\
\hline Precipitation & $\mathrm{cm}$ & $32.5(19.9-63.9)$ & Mean annual precipitation from 1979-2008 & $\begin{array}{l}\text { PRISM } \\
(800 \mathrm{~m})\end{array}$ \\
\hline $\begin{array}{l}\text { Time Since Fire } \\
\text { (TSF) }\end{array}$ & years & $19(1-33)$ & $\begin{array}{l}\text { Number of years since a fire burned an area using } \\
\text { data beginning at } 1980 \text {, or using } 1980 \text { as a reference } \\
\text { time for unburned plots }\end{array}$ & GIS $(90 \mathrm{~m})$ \\
\hline $\begin{array}{l}\text { Native Perennial } \\
\text { Grasses (NPG) }\end{array}$ & $\%$ & $20(0-68)$ & $\begin{array}{l}\text { Mean } \% \text { cover of native perennial grass at the plot } \\
\text { level }\end{array}$ & PhotoPoint \\
\hline $\begin{array}{l}\text { Exotic Perennial } \\
\text { Grasses (EPG) }\end{array}$ & $\%$ & $3(0-51)$ & $\begin{array}{l}\text { Mean } \% \text { cover of exotic perennial grasses at the plot } \\
\text { level }\end{array}$ & PhotoPoint \\
\hline $\begin{array}{l}\text { Exotic Forbs } \\
(\mathrm{EF})\end{array}$ & $\%$ & $2(0-24)$ & Mean $\%$ cover of exotic forbs at the plot level & PhotoPoint \\
\hline $\begin{array}{l}\text { Native Forbs } \\
(\mathrm{NF})\end{array}$ & $\%$ & $1(0-32)$ & Mean $\%$ cover of native forbs at the plot level & PhotoPoint \\
\hline $\begin{array}{l}\text { Exotic Annual } \\
\text { Grasses (EAG) }\end{array}$ & $\%$ & $28(0-96)$ & $\begin{array}{l}\text { Mean \% cover of exotic annual grasses at the plot } \\
\text { level (mostly cheatgrass; Bromus tectorum) }\end{array}$ & PhotoPoint \\
\hline Shrub & $\%$ & $6(0-54)$ & Mean $\%$ cover of shrubs at the plot level & PhotoPoint \\
\hline
\end{tabular}


Figure Captions

Figure 1. Triangles indicate the distribution of 1-ha plots $(n=358)$ that were sampled for harvester ants (Pogonomyrmex spp.) within southern Oregon and Idaho, USA, during 2008-2009 and 2013-2014. Inset shows the distribution of samples in a larger spatial context.

Figure 2. A) Percent cover of exotic annual grass (EAG), native perennial grass (NPG), and shrubs as a function of time since fire (xaxis). B) Proportion of plots occupied, and C) density (colony/100 $\mathrm{m}^{2}$ ) of harvester ant (Pogonomyrmex spp.) colonies as a function of time since fire. Error bars are 90\% CIs. Sample sizes for each category were as follows: $n=32$ (1-6 years), $n=26$ (7-21 years), $n$ $=29$ (22-31 years), $n=123$ (Unburned). Our Unburned group served as our control for comparisons across the time since fire gradient.

Figure 3. Standardized regression coefficients ( $\pm 90 \%$ CIs) from our A) occupancy model and B) density model that described the effect of covariates (x-axis) on harvester ants (Pogonomyrmex spp.). See Table 1 for variable descriptions.

Figure 4. A) Percent cover of exotic annual grass (EAG), native perennial grass (NPG), and shrubs as a function of restoration groupings (x-axis). B) Proportion of plots occupied, and C) density (colony/100 $\mathrm{m}^{2}$ ) of harvester ant (Pogonomyrmex spp.) colonies as a function of restoration groupings. Error bars are $90 \%$ CIs. Burned $(n=98)$ and Burned and Treated $(n=124)$ groups allow 
assessment of post-fire seeding (restoration) effects. The Unburned $(n=123)$ group was not burned and thus served as a reference state and basis for comparison. 


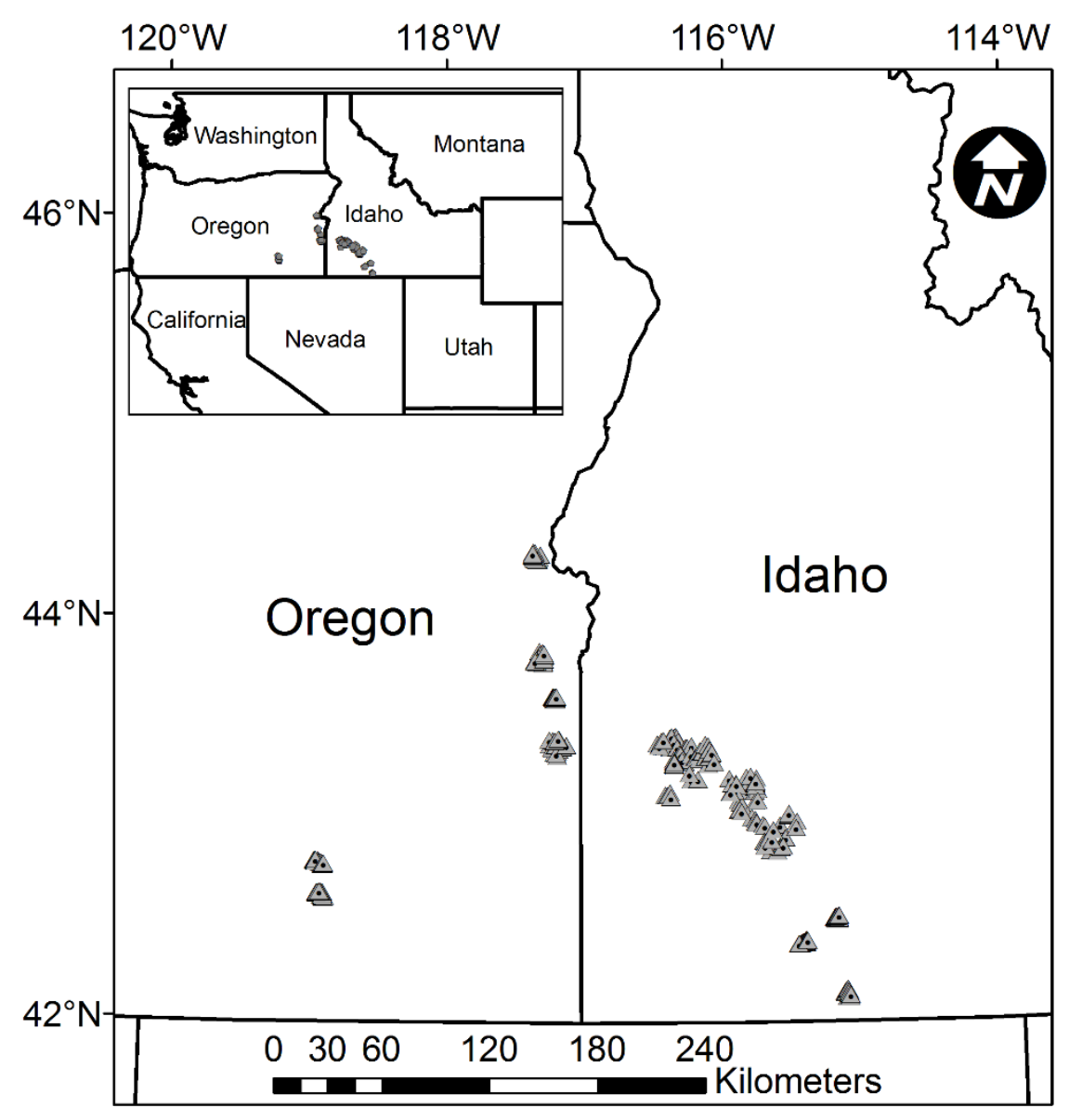

Figure 1 

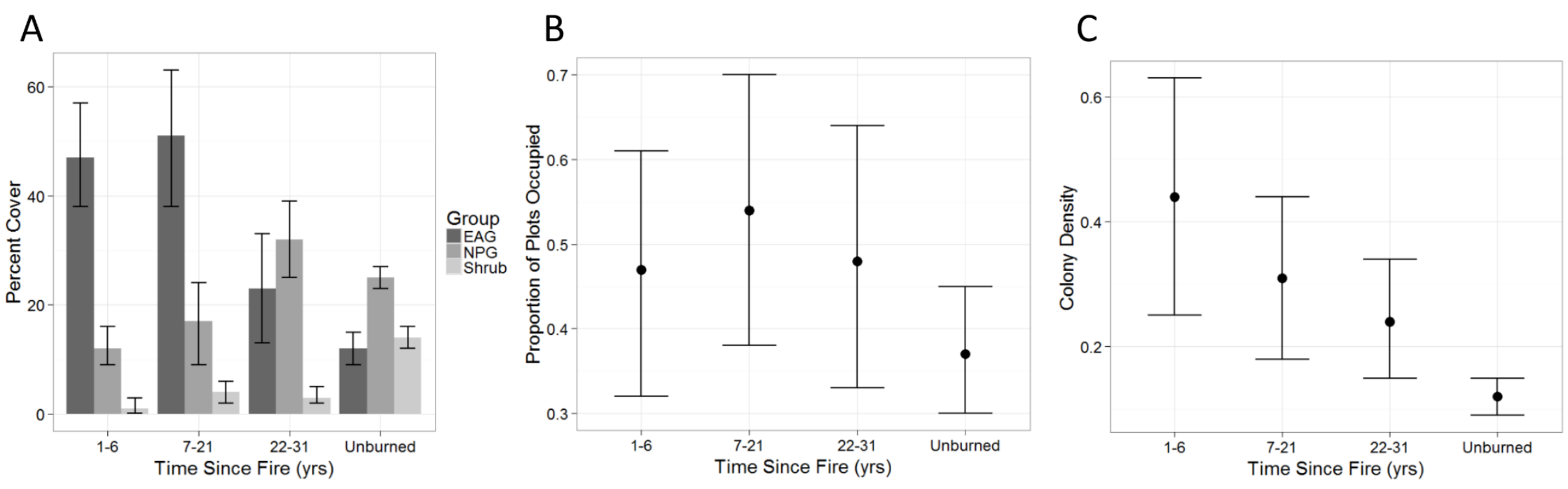

Figure 2 

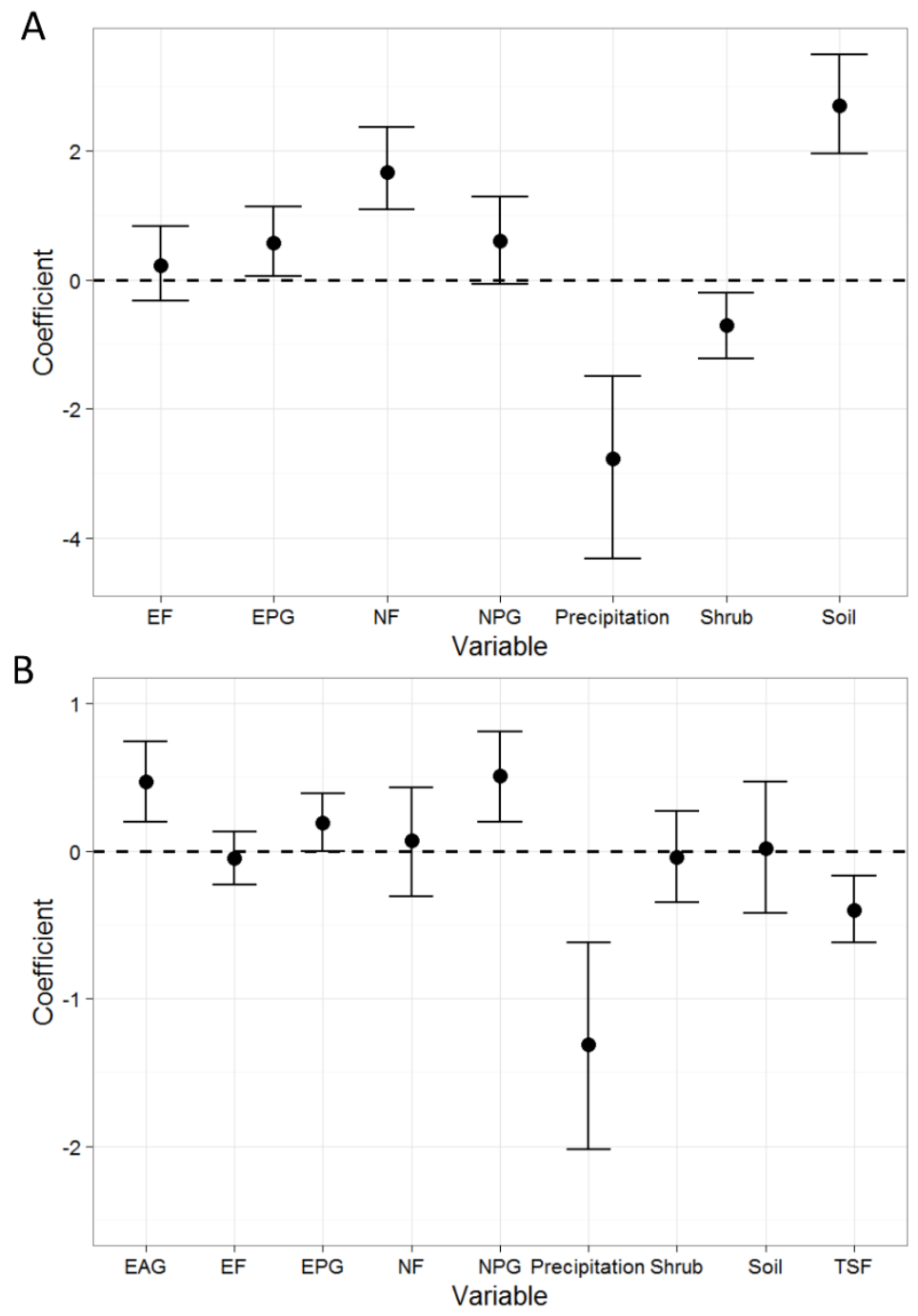

Figure 3 

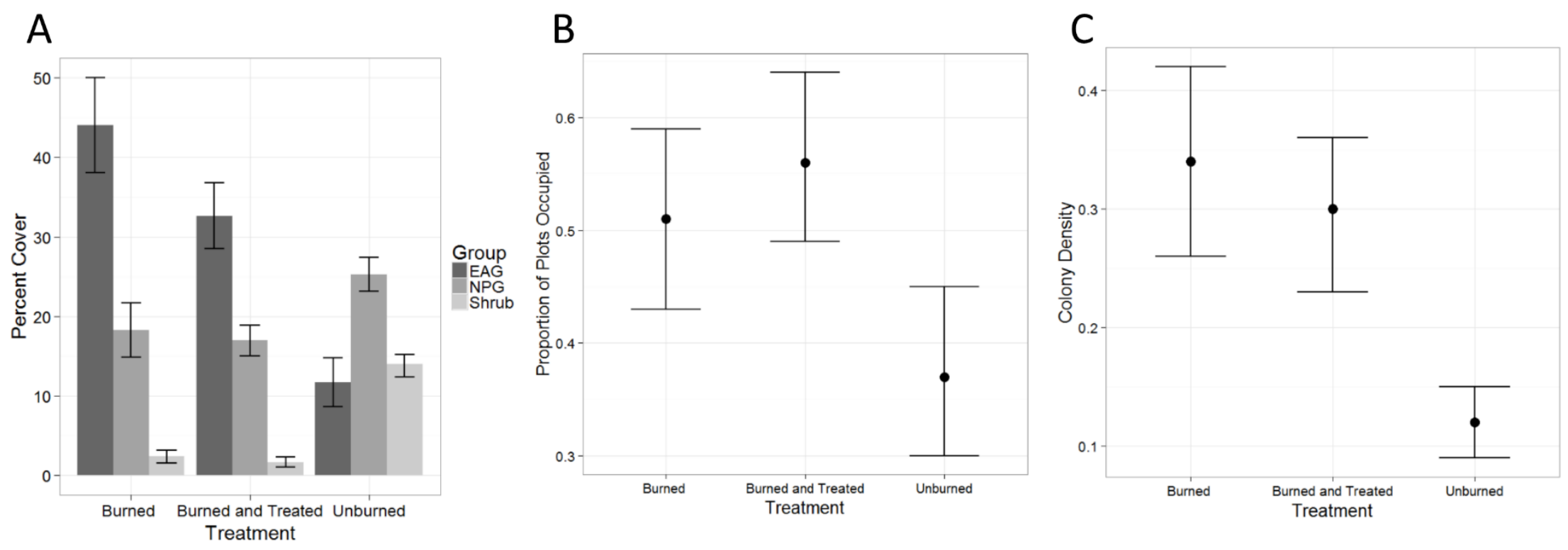

Figure 4 